\title{
EXCHANGE OF LAND: A MODEL OF SUSTAINING THE EXISTENCE OF LAND UNDER ADAT LAW
}

\author{
SRI HAJATI ${ }^{1}$, SRI WINARSI ${ }^{2}$, OEMAR MOECHTHAR ${ }^{*}$, ZUHAIRAH ARIFF ABD GHADAS $^{3}$ \\ ${ }^{1}$ Department of Jurisprudence, Faculty of Law, University of Airlangga, 60286 Surabaya, Indonesia. oemar.m@fh.unair.ac.id* \\ (Oemar Moechthar) \\ ${ }^{2}$ Department of Administrative Law, Faculty of Law, University of Airlangga, 60286 Surabaya, Indonesia. \\ ${ }^{3}$ Faculty of Law and International Relations, Universiti Sultan Zainal Abidin (UniSZA), 21300 Terengganu, Malaysia.
}

\begin{abstract}
The objective of the State is to ensure the welfare of the people as stipulated in the 1945 Indonesian Constitution. One of the ways to reach this objective is by protecting the rights of land usage and ownership by the people. However, customary land (tanah hak ulayat) belonging to the Indonesian adat community is under constant threat of extinction. This is due to the increasing relinquishment of communal land by the government in the face of rising need of lands in Indonesia, especially those designated for public utility. This possesses a problem for the adat community to sustain themselves. The purpose of this study is to provide a model recommendation to prevent the extinction of customary land as well as a solution to empower the adat community. This study uses the normative legal research methodology. The legal documents and legal resources are analysed by using statutory and conceptual approaches. Both approaches are significant to examine the existing laws in addition to analyse the factual challenges revolving the preservation of customary land by the adat community. This study found that the main cause leading to the extinction of customary land is the difficulty faced by the adat community to prove the status of communal land. This is encouraged by the lack of admissibility in the evidentiary materials and a lack of written laws providing the protection of customary land. Therefore, the ideal model to prevent the extinction of customary land is through the participation of adat community to sustain assets of land and the opportunity of exchange of lands under adat law. This study contributes to the existing literature on adat law in Indonesia.
\end{abstract}

Keywords: adat community, exchange of land, customary land tenure, ulayat right, land law.

Article Received: 18 October 2020, Revised: 3 November 2020, Accepted: 24 December 2020

\section{Introduction}

Land matters in Indonesia have amounted to become a source of conflicts. One of the conflicts is rooted the intertwinement of indigenous rights over customary land and ulayat (communal) rights. Currently, claims over land based on ulayat rights relating to communal land ownership and tenure are increasing. Even though such claims are relatively small in number, they cover an extensive range of territories and massively involve the inhabitants as opposed to individual land cases.

Such a conflict has been emerging since the New Order regime. As a matter of fact, to get information about the concept behind adat law concerning ulayat right the focal point of the development under the New Order administration was to create economic growth; such a policy, inevitably, requires establishments of industries. Industrialization, in turn, needs large areas of available lands. On the other hand, available lands designated for industrial areas are limited. The pragmatic way of providing lands for the industrialization policy is to compel indigenous people who inhabited and possessed their communal lands to sell their lands to companies that need the lands or exchange the lands with lands designated by the companies. The rapid development, consequently, has made adat law communities in some areas in Indonesia start to pay more attention to and reclaim land tenures that once were in the possession of their ancestors, known as the ulayat lands of adat law communities.

In today's world that focuses on development, the meaning and functions of land are no longer just related to mythical and religious beliefs like in the old days; rather, they perceive land from some aspects: social, economic, political, legal, defense, security and so on. Economically, land is regarded as a lifetime asset passed down through generations. It is, therefore, an investment for a 
better life in the future. This is due to the existence of land that goes way beyond human life expectancy. These factors drive men to consider land as a matter worth being paid attention to and delicately cared for; hence, efforts have been made to ensure their tenure over land. It is understandable because almost all aspects of life in today's society are inseparable from the need for land (Hajati, 2019). The basic philosophy that must be understood when we talk about land as adat rights is about the relationship between people and the land. This is closely related to kinship, power, leadership, livelihoods, rites and spiritual realm often called as 'religio-magical' relation (Hajati, et.al, 2016).

Upon realizing the importance and functions of land, the government has no alternative but to improve the management, regulation and administration of land that bring about wealth and prosperity in accordance with the governing laws and regulations. It is stated in the elucidation of Law No. 5 of 1960 concerning Basic Agrarian Law (hereinafter referred to as the UUPA) that one of the objectives of the UUPA is to create foundations that provide all citizens of Indonesia legal certainty on the rights over land. The general elucidation is a philosophical background of the Law. Referring upon the elucidation, the current highlight is on the steps to resolve these land problems that Indonesia takes as a developing nation are always in line with the interests of the people. Not only is the land needed by the people, but it is also needed by the government to develop the nation.

The recurring talks around land matters is ruislag (swap or exchange). Ruislag is a form of land swap, which means an exchange of a utilized or cultivated land for another land among the central government and regional governments. The main principle of such swap is that the government considers a designated land/building/territory as being out of place or no longer fits to the development plan.

\section{Literature Review}

\subsection{Adat Law in Indonesia}

Indonesian indigenous communities, or adat, has long been recognized to possess their own legal order, the adat law (Djojodigoeno, 1950). Ter Haar defined the adat community as: "groups of constant and organized society that has it own power, both tangible and intangible." (Hadikusuma, 2003). The criteria for adat groups is further laid down by the World Bank (Mariane, 2014): first, the group must be closely related with regional descendants and natural resources; second, the identity of the group is determined and others identified the group as members of a distinct cultural group; third, speak a native language that differs from the national language; fourth, obtain adat structures in social and political aspects; and fifth, the production is mainly oriented sub-system. Adat communities have their own adat laws that form a variety of policies that fit to their philosophy, moreover in terms of the management of natural resources (Husbani, 1997).

The recognition of adat law dated back to the Indonesian colonial era in 1891 (Pradhani, 2019). Prior to Indonesian independence from the Dutch and Japanese, the recognition of adat communities were based on religious law, predominantly in Java and Madura where Islamic law ruled the community (Hamami, 2003). This is criticized by Snouck Hurgenje to be a false acknowledgment, as adat law differs from religious law, though there is an influence of religious elements in adat law (Holleman, 1981). After the independence, the adat law started to gain more recognition within the Indonesian legal system and was normatively recognized through the Indonesian 1945 Constitution Article 18B (2). However, problems revolving the implementation of adat rights in land law remains a problem due to the relatively weak position of adat communities in Indonesian legislation (Bedner \& Huis 2008). Nonetheless, through constant challenges of modernity, adat law communities have not perished (Burns, 2004).

\subsection{Ulayat Rights in Indonesian Land Law}

The relation of the adat community and the land is linked with the concept of adat land rights (Husbani, 1997). It stems from the principle of adat 
rights as guideline in the management of natural resources, including managing how the adat authority should organize and plan the use of natural resources as well as establishing legal relations between the community and the land (Husbani, 1997). The adat authority is expected to resolve issues relating to the utilization of resources by outsiders (Husbani, 1997). It is a legal partnership rights of land instead of an individual right (Ruchiyat, 1984).

The Second Amendment of the Indonesian 1945 Constitution, Basic Agrarian Law, and Forestry Law have recognized customary rights of adat communities in Indonesia, including, inter alia, the ulayat right, or translated to right to avail or right of allocation (Priambodo, 2018). Ulayat rights as a judicial term can be defined as the attributed rights as an exclusive right of adat law communities, by which the community is granted authority to rule and manage the lands and all objects attached thereupon with the forces that both apply inward or outward of the communities (Ter Haar, 1999). According to Ter Haar, ulayat rights extended beyond just a land, but also the subject matters of ulayat rights consist of lands and waters, such as rivers and coastal waters, as well as autonomous vegetation such as trees, fruit plants and woods, along with wild animals inhabiting the territory of the communal lands (Ter Haar, 1999).

\section{RESEARCH METHODOLOGY}

The type of this research is a legal research. It is observed whether ulayat right or indigenous communal right is provided in laws and regulations. In doing so, a comparison will be made between the concept of adat law and the prevailing laws and regulations concerning land. It is also analyzed whether the laws and regulations overlap each other or lack coherence. In addition, judicial decisions are examined to get information whether adat law concerning land and that provides ulayat right remains observed by court.

The initial step of carrying out this research is to identify laws and regulations concerning land. Then, an interview is conducted with the Adat Chief (Village Chief) of Mahakam Ulu, located in
Dadimulya Sub-district, Samarinda Ulu District, Samarinda, East Kalimantan Province to get information about the concept behind adat law concerning ulayat right. Such information is of great relevance to define whether the concept was provided in laws and regulations. The information will also be reference whether judicial decisions reflect the concept held by adat law community.

The last step of this research is to give recommendation on the legal matter concerning land at hand. It is typical of legal research is not to verify hypothesis; instead, it gives prescription for what to be done in resolving the legal issues (Marzuki, 1995).

\section{Analysis and Discussion}

Ulayat rights are legal communal rights over land, as opposed to individual rights. Maassen and APG Hens in their book Agrarische regeling voor het Gouvernementsgebied van java en Madura defines ulayat rights as follows (Ruchiyat, 1984);

The term ulayat rights (beschikkingensrecht) means the rights of rural villages according to adat (customary laws) and the will to secure land tenure in their surrounding territories for the sake of the people or others (outsiders) by providing the villages with compensation, in this case the villages are more or less involved in the land clearing processes and are also responsible for the yet unfinished matters or cases taking place there.

The above definition shows that there are inward and outward forces play the role in the applications of ulayat rights. The inward forces mean that all members of adat law communities are entitled to reap the benefits from the lands, along with all objects attached upon them, to fulfill the needs of the members. While the outward forces of the rights mean that, in addition to their own members, people from outside the community may exercise the ulayat rights under the approval of the authority and are required to pay compensations. It is mentioned in the elucidation of Article 3 UUPA that what is referred to as the "ulayat rights and the like" is what the glossary of adat defines as the "beschikkingsrecht". 
The UUPA also does not specify ulayat rights as it is referred to in the adat law literatures as the beschikkingensrecht (Sumardjono, 2008). Ulayat rights as a judicial term means the attributed rights as an exclusive right of adat law communities, by which the community is granted authority to rule and manage the lands and all objects attached thereupon with the forces that both apply inward or outward of the communities (Ter Haar, 1999).

Therefore, ulayat rights display a legitimate relation between adat law communities being the subjects and their lands being the objects of the rights. The relation between adat law communities and their land territories is tenure-related. Another definition of ulayat rights is a set of authority and obligations of adat law communities over lands within their territories, which become the backbone of livelihood of the communities concerned.

The subjects of ulaya rights are the adat law communities. Each community is brought together by a communal law based on same geographical place of living (territorial) and based on genes (genealogy), which can be identified by its distinctive names in certain areas representing the clan, tribe, village, or province they are in/from and so forth. If an individual appears to be the subject of ulayat rights, the individual is the adat chief who is granted the authority from the relevant adat law community according to the provisions of the adat law. He personally is not the subject of ulayat rights, instead an officer of the adat law community who acts under the authority of such ulayat rights. The holders of ulayat rights are the adat law communities. Each community is brought together by a communal law based on the same geographical place of living (territorial) and based on genes (genealogy), which can be identified by its distinctive names in certain areas representing the clan, tribe, village, or province they are in/from and so forth. While, the subject matters of ulayat rights do not extend only to lands, but also to forests, waters (rivers, coastal waters) and vegetation that grow autonomously as well as animals in the wilderness. According to Ter Haar (Ter Haar, 1999) the subject matters of ulayat rights consist of lands and waters, such as rivers and coastal waters, as well as autonomous vegetation such as trees, fruit plants and woods, along with wild animals inhabiting the territory of the communal lands.

In Supreme Court Decision No: 2290 K/Pdt/2009 of 13 April 2010, it is evident how hard it was for the adat law community to substantiate evidence relevant to customary land and ulayat rights, despite the attempt made by the chief of Sakai Tribe to meet the requirement set forth in Article 3 of the UUPA concerning substantiation of the existence of adat law communities that should lead to their ulayat rights being protected by the government. The practice, however, is different in reality because the customary land was not given clear boundaries, hence the repudiation of ulayat rights of the adat law community by the judges, although in this case PT. Murini Wood Indah Industri complied with the provisions set forth in Article $28-31$ of the UUPA granting it the right of cultivation over the land (or locally known as the HGU). It can be substantiated that PT. Murini Wood Indah Industri had complied with the provisions in Article 28 paragraphs (1) and (2) by filing for such right of cultivation of 10-hectare land for agriculture, as well as with the provisions in Article 29 paragraphs (1) and (2) by substantiating the right of cultivation of the land granted in 2000 and against which a lawsuit was filed in 2008, which have not exceeded the 25- and 30-year period respectively. In addition, PT. Murini Wood Indah Industri, which is legally registered and domiciled in Riau, had also comply with the provisions of Article 30 paragraph (1) of the UUPA as regards entitlement to right of cultivation of the land for citizen of Indonesia or legal entity established under the Indonesian law and domiciled in Indonesia. Furthermore, the granting of the right of cultivation of land by the government reaffirmed that PT. Murini Wood Indah Industri had complied with the provisions of Article 31 of the UUPA, which basically means that the right of cultivation over the land is legally granted under the arrangements of the government. This brings us to the fact that there needs to be written regulations that specify and protect ulayat 
rights possessed by adat law communities. In practice, however, almost all ulayat rights cannot go through the substantiation phase because of the difficulty faced by adat law communities in substantiating their rights over land, which then leads to their customary lands being converted to state lands.

In State Administrative Court Decision of Kendari No: 01/G/2010/PTUN-KDI of 20 October 2010, similar difficulty to substantiate the rights over customary land is evident. The certification of customary land in the vocabulary of land law is known as the first initial land registration, or in other words the activity to register the land as an object previously unregistered. Thus, the decision on the case above made it impossible for the adat law community of Moronene to claim ownership or tenure over customary land. In addition, PT. Anugerah Alam Buana Indonesia already received a decision from the regent, Bombana, as regards the permission to mine gold in the land.

In Article 5 of the Regulation of the Minister of State for Agrarian Affairs/Chairman of Land National Agency No. 5 of 1999 concerning guidelines for dispute settlement on ulayat rights of adat law communities, it is stated that the determination of whether or not ulayat rights of certain adat law communities is still in effect falls within the jurisdiction of the relevant regional government, in which local adat law experts, as well NGOs and other institutions that manage the natural resources in the region are involved. In principle, the UUPA still recognizes the existence of ulayat rights. Such a recognition, however, comes with two conditions in relation to the "existence" and the "applications" of the rights. In other words, ulayat rights should prevail and be recognized provided that their factual existence is substantiated among the relevant adat law communities. And if so, the applications of the rights should furthermore be in certain ways so that they are in line with the national and state interests, which are based on unity and must not work against the superordinate laws and regulations as stated in Article 3 and the General Elucidation II point (3). The provisions in Article 3 of the UUPA are based on the recognition of ulayat rights in the National Land Law, being the highest titles to the lands within certain territories of adat law communities, and thus the lands are jointly owned by the inhabitants.

In Article 5 of the Regulation of the Minister of State for Agrarian Affairs/Chairman of Land National Agency No. 5 of 1999 concerning guidelines for dispute settlement on ulayat rights of adat law communities, it is stated that the definition of whether or not ulayat rights of certain adat law communities is still in force is made by regional government whose jurisdiction cover the site of the land, in which local adat law experts, as well NGOs and other institutions that manage the natural resources in the region are involved in making the definition. In principle, the UUPA still recognizes the existence of ulayat rights. Such a recognition, however, deals with two conditions in relation to the "existence" and the "applications" of the rights. In other words, ulayat rights should prevail and be recognized provided that their factual existence is substantiated among the relevant adat law communities.

The Regulation of the Minister of State for Agrarian Affairs/Chairman of Land National Agency No. 5 of 1999 concerning guidelines for dispute settlement on ulayat rights of the adat law communities, however, was revoked on 25 May 2015 and was declared no longer in effect upon the issuance of Regulation of the Minister of Agrarian Affairs and Spatial Planning/Chairman of Land National Agency No. 9 of 2015 concerning Establishment Procedures for Communal Rights over Communal Land of Adat Law Community and Community in Certain Territory.

In the event of a dispute takes place between an adat law community and the government or private institutions, the status of the communal land of the adat law community may lead to the community losing its asset, in the form of customary land (the communal land). Some court decisions on relevant dispute settlements in which the standings of adat law communities are relatively very weak, particularly in terms of substantiating the rights over their lands (communal lands). 


\subsection{Ruislag (Exchange) of Customary Land}

Quesnay elaborated that land is regarded as the only source of income and wealth. Agricultural is a productive sector, where land is believed to have the ability to produce a surplus, in terms of both quantity and quality, of raw resources and materials used in the manufacturing of goods (Sumitro, 2001). Adat law communities possess close relationships through long-standing interactions and adaptations with nature and natural resources, which make them capable of developing ways to maintain their survival by agreeing on common value system, organizational way of life, law in accordance with the conditions, and natural resources management, in terms of availability, in the areas they occupy (Utomo, 2016).

Initially, adat law communities were not always in harmony with nature. They have also caused environmental damages. Over the years though, they have tried to avoid recurring major mistakes because their survival is dependent on the integrity of their surrounding ecosystems where they collect food and build homes. Their understandings of the nature and its system are accumulated and passed down verbally through generations, which cannot be explained by scientific terms (Syafa'at, 1995). The acceleration of development apparently has costed many of the adat law communities their access to natural resources such as the forests, coasts, seas and lands, leading to diminishing organizations of adat and adat laws locally. This can happen due to them not being involved by the government in the planning, allocation, and ultimately the decision-making processes of land, forest, coastal and sea areas (Koentjaraningrat, et.al, 1993).

Article 1 point 19 of Government Regulation No. 27 of 2014 on The Management of State/Regionowned Property prescribes Exchange is the transfer of ownership of State/Region-owned Property made between the Central Government and the Regional Government, between the Regional Governments, or between the Central/Regional Government and other party with compensation in the form of property at least of equivalent value. In the Government Regulation, State-owned property consists of all property purchased or procured with the State Budget or procured through other lawful means. While Regional Government-owned Property consists of all assets purchased or procured with the Regional Government Budget or procured through other lawful means. It is stated in Article 33 (3) of the 1945 Constitution that : "The land, water and natural riches so contained shall be controlled by the State and exploited for the sake of the greatest benefit of the people."

Relying upon Article 33 (3) of the Constitution, it is implied that land ownership does not belong to the state, as opposed to what is encountered in western countries that adopt eminent domain practices before the introduction of UUPA. Article 33 (3) of the Constitution is further detailed by the articles in the UUPA. Article 2 paragraph (1) states that:

"On the basis of the provisions contained in Article 33 paragraph 3 of the Constitution and of the matters referred to in Article 1 of this Act, the land, water, and airspace, including the natural resources contained therein, are at the highest hierarchical level controlled by the State in its capacity as the whole people's organization of power"

Article 2 paragraph (1) of the UUPA indicates that it will be out of context if the government, on behalf of Indonesian people, acts as a land owner in order to achieve the objectives of Article 33 (3) of the Constitution (Parlindungan, 1994). Furthermore, paragraph (2) of Article 2 of the UUPA clarifies the meaning of state right of control, that the state is authorized to: (a) regulate and manage the allocation, usage, availability, and maintenance; (b) define and arrange legal relations between people; (c) define and arrange legal relations between people and legal acts concerning land, water, and airspace.

The authority attached to the state right of control gives the possibility for the governing organization to (Parlindungan, 1994) : (a) grant civil rights to both an individual or legitimate private organizations such as right of ownership, right of cultivation, right to build and right of use; (b) recognize certain public rights existed previously 
such as ulayat rights of adat law communities (Article 3 of the UUPA); (c) issue new law to the public associated with granting of right of management to government organizations or state/regional government-owned enterprises; (d) grant right of use (in particular), for an unlimited period and performance of tasks, such as the rights of use for foreign representative organizations.

Regarding ruilslag, Minister of Finance of the Republic of Indonesia issues Decree No. 350/KMK.O3/1994 concerning Procedures of Increasing State-owned Property/Wealth. The reason of issuing the decree is laid down in its consideration part of the decree. It states that the swap of state-owned property, which is conducted by a state department/institution involving building/office and or other necessities as one of the means to fulfil the needs of the department/institution for building/office and or residence along with the facilities, takes place because of the state budget does not cover such needs of the department/institution. The application of exchange should be properly arranged to avoid state loss. The relevant legal grounds for ruislag are Law No. 1 of 2004 on State Treasury and Government Regulation No. 27 of 2014 and Regulation of the Minister of Finance No: 96/PMK.06/2007. The procedure for ruislag is as follow:

1. Carry out valuation based on the actual conditions of the land or building that will be exchanged;

2. At the regency or municipal level, as a user of budget, the government should submit proposal from the institution to the provincial government, then it is transmitted to the Ministry of Home Affairs and it is approved by the Minister of Finance; Upon approval, the proposal is returned to the provincial government, which finally is sent back to the regency/municipal government;

3. Process the relinquishment of the land and the land is converted to be a state's land.

\subsection{Customary Land of The Adat Law Communities of Long Pahangai}

The collection of data for this study was conducted at the government office of Mahakam Ulu Regency, Penghubung Mahakam Ulu, Jalan Seruling RT. 36 No. 49, Dadimulya Sub-district, Samarinda Ulu District, Samarinda, East Kalimantan Province. In addition, the interview with the adat chief of Long Pahangai District, Mahakam Ulu Regency, Samarinda. Mahakam Ulu Regency whose capital is Ujoh Bilang is located in East Kalimantan Province and was established on 20 May 2013 under Law No. 2 of 2013. The total population of Mahakam Ulu Regency is 27,923 with a total area of $15,313.40 \mathrm{~km}^{2}$ (fifteen thousand three hundred thirteen point four square kilometer) spread over five districts: Long Hubung District, Laham District, Long Bagun District, Long Pahangai District and Long Apari District.

There is a hierarchy in the administration of the adat law community of Long Pahangai comprising different tasks and functions. First, the Adat Chief (Village Chief) who functions at the village level and deals with personal, domestic and internal affairs. Second, the Great Adat Chief at the district level who deals with the development of inhabitants of adat villages and acts as their counselor. Third, the Adat Committee/Presidium who functions at the regency level. In addition, there are three major Dayak ethnic groups in Mahakam Ulu, i.e. the Dayak Bahau Osak, Dayak Bahau Kenya and Bahau Usang. The three share the same Dayak ancestral root.

Natural terrains such as mountain backs and/or rivers, acts as the border between each of the customary land of the Dayak ethnic groups. If the terrain is flat, stakes are installed as land boundary markers. However, whether such land falls under customary land category and therefore registered is dependent on the subject of the rights. It is only customary for the inhabitants of the adat law communities in that territory to consider it as customary lands. As for substantiation of rights, certain regions have locally issued their Decree of the Regent concerning customary land recognition. 
The customary lands in Mahakam Ulu are categorized into two types : (1) Public Customary Lands, which are in the size of the kampong within the given territory. They is used for plantations and farms. The inhabitants rotate the management of the land in which an individual could run some small farms for at least five (5) years to ten (10) years, until the lands converted back to become customary lands. The ownership of Public Customary Lands is not transferable; (2) Private Customary Lands, which is owned by members of the adat law communities and whose ownership is now transferable (it was not transferable back then, only lending and borrowing instead).

Based on the functions, ulayat rights can be divided into two : First, Persona (Private), which falls into ulayat rights over certain communal land allowing an individual to benefit from the land, forest, water and all contained as a member included in such rights. He may cultivate the land and make it a source of his livelihood through farming. Second, Public, which falls into ulayat rights over certain communal land for social control, cohesiveness, as well as brotherhood. Those included in ulayat rights certainly will interact with each other. The interactions are based on the unwritten adat (customary laws). They think and act according to the rules that bind the members.

The indicators of existential being of communal land, indigenous land or customary land are the following:(Abdurrahman, 2007) (1) the community in it still forms a societal group (rechtsgemeenschap); (2) there is some kind of institutionalization in a form of adat apparatus; (3) there is a clear adat jurisdiction; (4) there is an official adat legal system and norms to which the community still adheres; and (5) livelihood is still dependent on foraging activities in the forests.

Therefore, customary rights are still recognized provided that: (1) there is a group of people who still feel that they are bound by an adat legal system as members of a certain community, recognize and practice what is regulated under in their daily life; (2) there is a designated customary land in which members of the community live and gain livelihood; (3) there are adat legal arrangements in effect pertaining to administration, control and cultivation of the customary land to which members of the community adhere.

In regards to disputes over land matters pertaining to customary land between adat law communities and companies, it often takes place within the same land territory. Adat law communities are never involved in the deliberation on the use of their customary lands. If a company intends to access a customary land, it is common for the company to take relevant Decree of the Regent concerning management of forests within the customary land territory and deliver it to the adat chief of the village. The adat chief then reports to the great adat chief and if such request is approved, the company may manage the forests within the customary land territory. If the request is denied, however, the company is not allowed to do so.

In order to achieve sustainable development as stated in Article 10 of Law No. 2 of 2012 on land procurement for public interest, the land for public interest shall be allocated for the development of: (a) matters concerning national defense and security; (b) public roads, toll roads, tunnels, railways, rail stations, and railway operational facilities; (c) reservoirs, dams, weirs, irrigations, drinking water channels, water and sanitary sewers, and others irrigation facilities; (d) ports, airports, and terminals; (e) oil, gas and geothermal infrastructures; (f) power plants, transmitters, relay stations, network and power distribution; (g) government's telecommunication and information networks; (h) landfills and waste treatment facilities; (i) government/regional government's hospital; (j) public safety facilities; (k) government/regional government's public cemeteries; (1) social facilities, public facilities and green open spaces; $(\mathrm{m})$ nature reserves and cultural reserves; (n) government/regional government/village offices; (o) solutions to urban slums and/or land consolidation, as well as housing for low income communities with lease status; (p) education infrastructures or government/regional government's schools; (q) government/ regional government sport infrastructures; and (r) public markets and public parking lots. 
The adat law communities in Long Pahangai District, Mahakam Ulu Regency are more open to the allocation of their customary lands for the sake of development provided that the lands are used for the constructions of roads due to insufficient access in and out of the territory. They rely on rivers for transport or access. Roads are considered more advantageous because the adat law communities of Long Pahangai may have easier access to selling their fish, forest and agricultural commodities.

According to Emil Salim (Salim, 1996), sustainable development requires approaches that take into account environmental development, more specifically eco-development. Emil Salim elaborated that such sustainable development model has several characteristics in its ecological applications such as: (1) take into account the costs for environmental damages and rehabilitations for the sake of today's and tomorrow's generations; (2) prioritize poverty eradication with a focus on those below the poverty line; (3) maintain and balance the right environmental carrying capacity to support the life of supporting ecosystem, by directly or indirectly sustaining its functions and capacity; (4) adopt environmentally friendly technologies matching the environmental carrying capacity in the optimal utilizations of natural resources for sustainable long-term prosperity; (5) drive the sustainable economic, social and ecological aspects of every activity and or effort to give significant impacts to the living environment and nature; (6) incorporate sustainable ecological paradigm in efforts to improve or sustain the capacity and role of the ecosystem in supplying natural resources; (7) implement environmentally friendly development processes and procedures suitably, congruently and harmoniously taking into account the functional sustainability and capacity aspects of the ecosystem in order to support the living environment and the interests of all beings today and tomorrow.

\subsection{The Existence of Ulayat (Communal) Lands of Adat Law Communities}

Ulayat rights to a certain adat law community may originate from separation from its parent adat law community in order to become an independent adat law community whose customary land is within a part of the territory of the parent adat law community (Harsono, 2008). The laws and regulations do not clearly specify the arrangements of ulayat rights, which to some were known as communal rights. To refer to ulayat right, Van Vollenhoven introduced the term beschikkingensrecht, which was widely accepted by the public and is used until now. Beschikkingensrecht is basically the right of ownership over land and only exists in Indonesia. A right that may not be broken that is based on religious values.

Law No. 5 of 1960 also does not specify about ulayat rights, which in the vocabulary of adat law is known as beschikkingensrecht (Sumardjono, 2008) From juridical point of view, ulayat rights means the rights inherent to adat law communities that gives them the special competence in the form of authority/power to manage and take care of their lands and all they contain with forces that apply both inward and outward of the communities (Sudiyat, 1999). Therefore, ulayat rights display a legitimate relation between adat law communities being the subjects and their lands being the objects of the rights. The relation between adat law communities and their land territories is tenurerelated. Another definition of ulayat rights is a set of authority and obligations of adat law communities over lands located within their territories, which become the backbone of livelihood of the communities concerned.

The subjects of ulayat rights are the adat law communities. Each community is brought together by a communal law based on same geographical place of living (territorial) and based on genes (genealogy), which can be identified by its distinctive names in certain areas representing the clan, tribe, village, or province they are in/from and so forth. If an individual appears to be the subject of ulayat rights, the individual is the adat chief who is granted the authority from the relevant adat law community according to the provisions of the adat law. He personally is not the subject of ulayat rights, instead an officer of the adat law community who acts under the authority of such ulayat rights. 
Meanwhile, the objects of ulayat rights do not extend only to lands, but also to forests, waters (rivers, coastal waters) and vegetation that grow autonomously as well as animals in the wild. According to Ter Haar (Ter Haar, 1999), the objects of ulayat rights are comprised of lands and waters, such as rivers and coastal waters, as well as autonomous vegetation such as trees, fruit plants and woods, along with wild animals inhabiting the territory of the communal lands. We can see that a communal land may have the following traits (Sudiyat, 1999) : (1) only the relevant adat law community and inhabitants have the right to cultivate the lands within their jurisdiction or land territory; (b) Any party from outside of the community may only use the lands upon approval of the local adat chief. Without the approval of an adat chief/leader, such use is considered a violation; (c) The use of communal lands is only for the benefit of members of the adat law community. Use for other purposes shall first gain approval from the adat chief/leader; (d) communal lands may not be transferred to other parties; and (e) ulayat rights also cover cultivated lands and already include individual rights.

Regulation of the Minister of State for Agrarian Affairs/Chairman of National Land Agency No. 5 of 1999 concerning guidelines for dispute settlement on ulayat rights of adat law communities, however, was revoked on 25 May 2015 and no longer in effect upon the issuance of Regulation of the Minister of Agrarian Affairs and Spatial Planning/Chairman of National Land Agency No. 9 of 2015 concerning establishment procedures for communal rights over communal land of adat law community and community in certain territory, which was annulled by Regulation of the Minister of Agrarian Affairs and Spatial Planning/Chairman of National Land Agency No. 10 of 2016 concerning establishment procedures for communal rights over communal land of adat law community and community in certain territory. According to Law No. 5 of 1967, all forests within the territory of the Republic of Indonesia and all natural resources contained are controlled by the state. It does not mean that that statement waives the rights of adat law communities over communal forests. In this regard, ulayat rights of adat law communities are recognized, provided that they can still be substantiated in reality and their applications shall not be in contrast with national interest and superordinate laws and regulations.

\subsection{Judicial Decisions Concerning Disputes Over Communal Lands Of Adat Law Communities}

In the event of a dispute between an adat law community and the government or private institutions takes place, the status of the communal land of the adat law community may lead to loss of customary land (the communal land), which is the community asset. Some court decisions indicates that the standings of adat law communities are relatively very weak.

It is appropriate to analyze Supreme Court Decision No: $2290 \mathrm{~K} / \mathrm{Pdt} / 2009$, on a dispute between the chief of Sakai Bathin Tribe in Pematangpudu Village, Baginda Raja Puyan, and PT. Murini Wood Indah Industri (hereinafter referred to as the PT. MWII) whos domiciles in Bengkalis (Riau Province). From the decision, it is found that it is very hard for the adat law community to substantiate evidence relevant to customary land and ulayat rights, despite the fact that the attempt made by the chief of Sakai Tribe to meet the requirements set forth in Article 3 of the UUPA concerning substantiation of the existence of adat law communities that should lead to their ulayat rights being protected by the government Since in reality no clear boundary mark of customary land is made, it leads to repudiation of ulayat rights of the adat law community by the judges. Complying with the provisions set forth in Article 28-31 of the UUPA, PT. MWII is granted the right of cultivation over the land (or locally known as the HGU). It can be inferred that PT. MWII had complied with the provisions in Article 28 paragraphs (1) and (2) by filing for the right of cultivation of 10-hectare land for agriculture, as well as that with the provisions in Article 29 paragraphs (1) and (2) by substantiating the right of cultivation of the land granted in 2000 and against which a lawsuit was filed in 2008, which have not 
exceeded the 25- and 30-year period respectively. In addition, PT. MWII, which is legally registered and domiciled in Riau, had also comply with the provisions of Article 30 paragraph (1) of the UUPA that is considered as entitle to have the right of cultivation over land for Indonesian citizens or legal entity established under the Indonesian law and domiciled in Indonesia. The granting of the right of cultivation of land by the government reaffirmed that PT. MWII had complied with the provisions of Article 31 of the UUPA, which mainly means that the right of cultivation over the land is legally granted under the arrangements of the government. Relying upon the fact, the need for written regulations that specify and protect ulayat rights possessed by adat law communities may be considered. In practice, however, almost all ulayat rights cannot go through the substantiation phase because of some complicated procedures and invisible factors faced by adat law communities in substantiating their rights over land, which then leads to their customary lands being converted to state's lands.

\section{Conclusion}

The arrangements pertaining to ulayat rights are still scattered sporadically in different laws and regulations in Indonesia, and merely still within the scope of recognizing and respecting such rights of adat law communities. The recognition formally specified in the laws and regulations is never implemented, which causes no protection under the law. The lack of clarity in defining the scopes of ulayat rights often becomes a source of conflict pertaining to customary land matters. If a dispute takes place between the government and an adat law community or between a company and an adat law community, the rights of the adat law community are often hard to fight for in the sense that there is often no support and repudiation of their rights. This kind of condition seems to be ripping off the land that becomes the source of livelihood of the community. Ruislag is one of the means to retain rights over land, by exchanging lands, by which adat law communities still maintain access to land usage that will continue to sustain their livelihood.

\section{Recommendation}

Adat law communities need to cooperate in order to define the scopes of ulayat rights. The cooperation can vary in the level of involvement (Malek, et. al , 2019). It is extremely crucial to define the scope of the existing adat law communities or ulayat rights. Therefore, there shall be a clear-cut formulation regarding definition of such scopes because each territory is different; this is the reason why it needs to be provided in the regional government regulations. Regional governments and village administrations handling specific matters related to adat laws in the villages need to set regional regulations at the regency/municipality level concerning protection of ulayat rights of the local adat law communities, which are enforced by the adat village administrations through their regulations at the village level that also include the definition of land size and borders between a kampong and another. Conflicts due to lack of clarity would not occur if there are certainties under the law regarding land matters. Companies that are denied the right to manage the forests may wrongly provoke adat/village chiefs and great adat chiefs and turn them against one another so that customary lands are divided, then companies eventually gain access to the given customary lands.

\section{REFERENCES}

[1] Abdurrahman. (2007). Meneliti Keberadaan Hak Ulayat di Kalimantan. Presented at Pelatihan Tenaga Peneliti Dalam Rangka Penelitian Hak Ulayat Di Kabupaten Kota Baru, Fakultas Hukum Universitas Lambung Mangkurat.

[2] Bedner, A. \& Huis, S. v. (2008). The Return of the Native in Indonesian Law: Indigenous Communities in Indonesian Legislation. Bijdragen Tot de Taal-, LandEn Volkenkunde, 164(2), 165-193. https://doi.org/10.1163/2213437990003655 
[3] Burns, P. (2004). The Leiden Legacy: Concepts of Law in Indonesia. KITLV Press.

https://www.researchgate.net/publication/4 1017125_The_return_of_the_native_in_In donesian_law_Indigenous_communities_i n_Indonesian_legislation

[4] Djojodigoeno. (1950). Adat Law in Indonesia. MCMLI Jajasan Pembangunan.

[5] Hadikusuma, H. (2003). Pengantar Hukum Adat Indonesia. Mandar Maju.

[6] Hajati, S, et.al. (2016). The Existence Of Adat Land Post-Enactment Of Law Number 6 Year 2014 On Village. Jurnal Dinamika Hukum, 16(3), 227-234. https://doi.org/http://dx.doi.org/10.20884/1 .jdh.2016.16.3.707

[7] Hajati, S. (2019). Application of Agreement Principles in Land Procurement for Development Public Interest. Yuridika, 24(2), 366. https://doi.org/http://dx.doi.org/10.20473/y dk.v34i2.12641

[8] Hamami, T. (2003). Kedudukan dan Eksistensi Peradilan Agama dalam Sistem Tata Hukum di Indonesia. Alumni.

[9] Harsono, B. (2008). Hukum Agraria Indonesia, Sejarah Pembentukan UUPA dan Pelaksanaannya, Jilid 1, Hukum Tanah Nasional. Djambatan.

[10] Holleman, J. (Ed.). (1981). Van Vollenhoven on Indonesian Adat Law. KITLV.

[11] Husbani, F. (1997). Kajian Atas Pengakuan Hak dan Eksistensi Masyarakat Adat dalam Peraturan Perundang-undangan Lingkungan Hidup di Indonesia. Jurnal Hukum Lingkungan, 44, 88.

[12] Koentjaraningrat, et.al. (1993). Masyarakat Terasing di Indonesia. Gramedia.

[13] Malek, J. A., et.al. (2019). Understanding the issues of citizen participation. Journal of Nusantara Studies. Journal of Nusantara Studies (JONUS), 4(1), 1-22. https://doi.org/https://doi.org/10.24200/jon us.vol4iss1pp1-22
[14] Mariane, I. (2014). Kearifan Lokal Pengelolaan Hukum Adat. RajaGrafindo Persada.

[15] Marzuki, P. M. (1995). Penelitian Hukum. Kencana Prenada Media Group.

[16] Parlindungan, A. . (1994). Komentar Atas Undang-Undang Pokok Agraria. Mandar Maju.

[17] Pradhani, S. I. (2019). Dynamics of Adat Law Community Recognition: Struggle to Strengthen Legal Capacity. Mimbar Hukum, 3(2), 280. https://jurnal.ugm.ac.id/jmh/article/view/3 4032

[18] Priambodo, B. B. (2018). Positioning Adat Law in the Indonesia's Legal System: Historical Discourse and Current Development on Customary Law. Udayana Journal of Law and Culture, 02(2), 144.

[19] Ruchiyat, E. (1984). Politik Nasional Sampai Orde Baru. Alumni.

[20] Salim, E. (1996). Pembangunan Berkelanjutan Dalam Bidang Sumber Daya Alam. Kementerian Lingkungan Hidup.

[21] Sudiyat, I. (1999). Hukum Adat Sketsa Asas. Liberty.

[22] Sumardjono, M. S. . (2008). Kebijakan Pertanahan: Antara Regulasi dan Implementasi. Kompas.

[23] Sumitro. (2001). Konsep Pertanahan Nasional. Alfabeta.

[24] Syafa'at, R. (1995). Perlindungan Hukum Hak Adat Kelautan dalam Pengelolaan Sumber Daya Laut: Studi Kasus Masyarakat Nelayan Kedungcowek, Kenjeran-Surabaya. Universitas Indonesia.

[25] Ter Haar, B. (1999). Asas-Asas dan Susunan Hukum Adat (terjemahan: Soebakti Poesponoto (Ed.)). Pradnya Paramita.

[26] Utomo, L. (2016). Hukum Adat. PT. Rajagrafindo Persada. 